\title{
PENGARUH DOSIS PUPUK KANDANG AYAM \\ TERHADAP PERTUMBUHAN DAN HASIL \\ UBI JALAR (Ipomea batatas L) \\ VARIETAS CILEMBU
}

\author{
Aksameri Dolmo ${ }^{(1)}$ Imaculata Fatima $^{(2)}$ Yustina M.S Wonga Pu'u ${ }^{(3)}$ \\ Program Studi Agroteknologi, Fakultas Pertanian \\ Universitas Flores \\ ashdolmo@yahoo.co.id
}

\begin{abstract}
The study aims at determining, firstly, the effect of chiken manure dose on the growth and crop result of sweet potato (Ipoma batatas), Cilembu Variety, secondly, determining the optimum dose of chiken manure which can lead the best of growth and yield of sweet potato (Cilembu variety).

Method used at this research is completely randamized design, and the treatmens are $\mathrm{K} 0$ (non fertilizer), K1 (dose of 10 tons/ha), K2 (dose of 20 tons/ha), K3 (dose of 30 tons/ha). Observation variables in this study are the length of the rod, number of leaves, leaf area, number of wet bulb per plant, berangkasan weight, wet weight of bulb per plant, length of bulb, diameter of bulb, and weight of wet bulb per hectare.

The result of this research indicate that the giving of chicken manure, giving a good influence at the growth and yiels of Cilembu sweet potato and real affect long stem at the age of 2, 6, and 8 mst of age, and wide leaf index at age 2, 4, and 6 mst. Production components have significantly affect for berangkasan weight, wet weight of bulb per plant, length of bulb, diameter of bulb and weight of wet bulb per hectare.

The optimum dose of chicken manure was obtained with a dose of 20 tons per hectare which can raise the growth of stem length of Cilembu Sweet Potato $(80,85 \mathrm{~cm})$ and the crop of Cilembu sweet potato $(731,72 \mathrm{~kg} / \mathrm{ha})$.
\end{abstract}

Keywords: chicken manure, dosage, sweet potato

\section{PENDAHULUAN}

Tanaman ubi jalar (Ipomoea batatas $L$ ) merupakan tanaman pangan golongan ubi-ubian yang berasal dari Amerika Latin (Martin, J.H., and W.H.
Leonard, 1967). Petani di Indonesia pada umumnya membudidayakan ubi jalar karena mudah pengelolaannya dan tahan terhadap kekeringan serta dapat tumbuh pada berbagai macam jenis 
Aksameri: Pengaruh dosis pupuk kandang ayam

tanah (Sarwono, Lingga, Rahardi, Raharja, Afriastini, Wudianto dan Apniaji, 1990). Tanaman ubi jalar merupakan salah satu tanaman penghasil karbohidrat keempat setelah padi, jagung dan ubi kayu. Kandungan gizinya terutama pada kandungan beta karoten cukup tinggi dibandingkan dengan jenis tanaman pangan lainnya, terutama pada varietas ubi jalar cilembu yang warna daging ubinya krem kemerah-merahan (Juanda dan Cahyono, 2000).

Varietas Cilembu digolongkan sebagai varietas unggul yang berdaya hasil di atas 20 ton/hektar, berumur pendek/genjah (3 bulan), rasa ubi enak dan manis, tahan terhadap hama penggerek umbi (Cylas sp) dan penyakit kudis yang disebabkan oleh cendawan (Elsinoe sp), kadar karotin tinggi di atas $10 \mathrm{mg} / 100$ gram, dan serat ubi relatif rendah (Wasetiawan, 2009).

Produksi ubi jalar pada petani ditingkat nasional sebesar 7,3 ton umbi basah perhektar, jumlah produksi ini masih tergolong rendah bila dibanding produksi rata-rata yang bisa mencapai lebih dari 20 ton umbi basah perhektar (Sarwono $\quad d k k, \quad$ 1990). Potensi produktifitas ubi jalar Cilembu yang di uji di lahan percontohan Dinas
Pertanian Tanaman Pangan dan Peternakan Kabupaten Ende sebesar 23 ton/ha. Hal ini optimis bisa diharapkan dengan diterapkannya dan didayagunakannya bibit jenis unggul yang dewasa ini belum begitu banyak di lakukan oleh petani di Kabupaten Ende.

Peningkatan produktifitas tanaman ubi jalar varietas cilembu merupakan upaya untuk meningkatkan pendapatan petani. Oleh karena itu perlu dilakukan perbaikan teknik budidaya diantaranya usaha pemupukan organik yang sesuai dengan kesuburan tanah. Fortuno, E.M., M.B Catany And F.G. Vilamayor, Gr (1996) mengatakan bahwa salah satu cara yang dapat dilakukan untuk memenuhi hara dan meningkatkan hasil tanaman ubi jalar yaitu dengan menggunakan pupuk organik. Menurut Yuwono, M., Basuki, N., Agustin, L (2002) pertumbuhan dan hasil ubi jalar yang mendapat perlakuan pupuk organik 20 ton/ha menghasilkan hasil terbaik dibandingkan dengan penggunan pupuk anorganik.

Pupuk organik yang dapat memperbaiki sifat-sifat tanah seperti sifat fisik, kimia dan biologis tanah salah satunya adalah pupuk kandang ayam. Sifat fisik yang dipengaruhi adalah memperbaiki struktur tanah, 
meningkatkan daya tahan dan daya serap air, dan memperkuat agregat tanah. Sifat kimianya adalah kemampuan tanah untuk menyerap kation, meningkatkan kandungan bahan organik tanah dan sebagai sumber unsur hara makro-mikro serta menaikkan $\mathrm{pH}$ tanah pada tanah-tanah masam. Sifat biologisnya dapat meningkatkan aktivitas mikroorganisme tanah karena pupuk kandang ayam mempunyai $\mathrm{C} / \mathrm{N}$ ratio yang tinggi sehingga sangat baik sebagai sumber energi bagi mikroorganisme. Dengan pemberian pupuk kandang ayam maka akan dapat meningkatkan kandungan $\mathrm{N}, \mathrm{P}, \mathrm{K}$ dalam tanah seperti unsur $\mathrm{N}$ yang diperlukan tanaman dalam vegetatif, sehingga mempercepat pertumbuhan tanaman (Riyo Sumekto, 2006).

Pupuk kandang ayam adalah pupuk organik yang berasal dari kotoran ayam, baik berupa padatan (feces) yang bercampur sisa makanan, ataupun urine (Riyo sumekto, 2006). Hasil penelitian Sortha (2006) menunjukan bahwa pupuk kandang ayam mengandung $\mathrm{N}$ yang cukup tinggi yakni 3,6\%; 2,9\% $\mathrm{P}$; dan 3,4 \% K dengan perbandingan $\mathrm{C} / \mathrm{N}$ ratio 8/3. Soemartono (2006) mengemukakan bahwa tanaman ubi jalar lebih banyak membutuhkan unsur $\mathrm{N}$ dan K sedangkan unsur $\mathrm{P}$ sedikit.

Hasil analisis tanah sebelum dan sesudah pemberian pupuk kandang ayam memperlihatkan adanya perubahan unsur-unsur hara yang penting. Menurut Setyamidjaja (1996), tanah podsolik yang miskin unsur hara, reaksi tanah masam, dan KTK tanah rendah, setelah pemberian pupuk kandang 20 ton/ha, kandungan unsur a menjadi sedang sampai tinggi, reaksi tanah agak masam dan KTK tinggi. Hal serupa terjadi pada tanah latosol. Pemberian pupuk kandang ayam dengan dosis 20 ton/ha dapat meningkatkan umbi ubi jalar varietas lokal hingga mencapai $85 \%$ bila di bandingkan dengan pupuk kandang lainnya (Tohari Yusuf, 2009).

Berdasarkan kenyataan ini pupuk kandang ayam menjadi salah satu alternatif dalam penyediaan unsur hara yang diperlukan bagi tanaman ubi jalar. Namun demikian diperlukan juga ketepatan dosis dalam pengaplikasian pupuk kandang ayam di lapang khususnya pada kondisi tanah yang relatif sama dengan kondisi tanah di kebun pecobaan. Untuk hal tersebut maka perlu dilakukan penelitian mengenai pengaruh dosis pupuk 
kandang ayam terhadap pertumbuhan dan hasil ubi jalar (Ipomea batatas L) varietas Cilembu.

\section{METODE PENELITIAN}

Penelitian dilaksanakan di kebun percobaan Fakultas Pertanian, Universitas Flores, di Desa Lokoboko Kecamatan Ndona, Kabupaten Ende. Tempat ini berada pada ketinggian sekitar $500 \mathrm{~m}$ di atas permukaan laut, suhu rata-rata $27,45-31{ }^{\circ} \mathrm{C}$ dan curah hujan berkisar antara 1.508 sampai dengan $2.750 \mathrm{~mm}$ pertahun, jenis tanah lempung berpasir. Penelitian ini dilaksanakan pada bulan November 2010 - April 2011 (BPP Ndona, 2009).

Kesuburan tanah di Desa Lokoboko, Kecamatan Ndona, Kabupaten Ende masih tergolong rendah. Berdasarkan hasil analisis tanah (lampiran 4) ternyata pasir berlempung, pH mineral $(6,5), \mathrm{C}$ organik $(1,66 \%)$, N-total $(0,17 \%), \mathrm{P}(10,94 \mathrm{ppm})$ dan K (0,36 ppm) (Murdaningsih, 2009).

Rancangan percobaan yang digunakan \$dalam penelitian ini adalah Rancangan Acak Kelompok (RAK) dengan empat perlakuan dengan taraf :

K0 : kontrol (tanpa pupuk)

$\mathrm{K} 1$ : dosis 10 ton/ha $(0,6 \mathrm{~kg} /$ guludan $)$

$\mathrm{K} 2$ : dosis 20 ton/ha (1,2 kg/guludan)

$\mathrm{K} 3$ : dosis 30 ton $/$ ha ( $1,8 \mathrm{~kg} /$ guludan $)$
Perlakuan ini di ulang sebanyak 5 kali sehingga terdapat 20 unit petak percobaan. Variabel Pengamatan, Panjang Batang (cm), .Jumlah Cabang Pertanaman, Jumlah Daun (Helai), Luas Daun Berat Basah Total Pertanaman (kg),Jumlah Umbi Basah per, Berat Basah umbi pertanaman (kg), Berat Umbi Basah per Ha, Panjang Umbi $(\mathrm{cm})$, Diameter Umbi $(\mathrm{cm})$. Analisis Data Data hasil pengamatan dianalisis dengan sidik ragam sesuai dengan rancangan yang digunakan. Apabila perlakuan menunjukan pengaruh nyata terhadap variabel yang diamati, maka dilanjtkan dengan uji BNT taraf 5\% (Gomez dan Gomez, 1995).

\section{HASIL DAN PEMBAHASAN}

\section{VARIABEL PERTUMBUHAN}

Panjang Batang (cm)

Hasil analisis sidik ragam menunjukan bahwa pemberian pupuk kandang ayam berpengaruh nyata terhadap panjang batang tanaman ubi jalar cilembu pada umur 2, 6 dan 8 MST, dan tidak berpengaruh nyata pada umur 4 MST (Tabel 4.1). 
Aksameri: Pengaruh dosis pupuk kandang ayam

Tabel 1.1 Rataan Panjang Batang Tanaman Ubi Jalar Cilembu (cm) akibat Perlakuan Dosis Pupuk Kandang Ayam Sebagai Sumber Bahan Organik pada Berbagai Umur Pengamatan.

\begin{tabular}{lcccc}
\hline Perlakuan & \multicolumn{4}{c}{ Rataan panjang batang pada umur (mst) } \\
\cline { 2 - 5 } & 2 & 4 & 6 & 8 \\
\hline $\mathrm{K}_{0}$ & $16,15_{\mathrm{a}}$ & 45,65 & $59,45_{\mathrm{a}}$ & $67,05_{\mathrm{a}}$ \\
$\mathrm{K}_{1}$ & $17,25_{\mathrm{ab}}$ & 45,75 & $60,85_{\mathrm{a}}$ & $67,75_{\mathrm{a}}$ \\
$\mathrm{K}_{2}$ & $19,15_{\mathrm{bc}}$ & 54,95 & $72,40_{\mathrm{b}}$ & $80,85_{\mathrm{b}}$ \\
$\mathrm{K}_{3}$ & $20,65_{\mathrm{c}}$ & 52,55 & $72,05_{\mathrm{b}}$ & $78,85_{\mathrm{b}}$ \\
\hline BN T 5\% & 2,87 & $\mathrm{TN}$ & 10,61 & 11,90
\end{tabular}

Keterangan : Angka yang diikuti oleh huruf yang sama pada kolom yang sama menunjukan tidak berbeda nyata pada taraf $5 \%$ uji BNT.

Pemberian pupuk kandang ayam pada umur 2, 6 dan 8 mst tidak berbeda nyata pada semua perlakuan tetapi berbeda nyata dengan kontrol (tanpa pemberian pupuk) dan dosis 10 ton/ha. Hal ini menunjukan bahwa penambahan pupuk kandang ayam dapat mempengaruhi pertumbuhan tanaman ubi jalar cilembu khususnya pada panjang batang tanaman. Pada umur pengamatan 6 dan 8 mst perlakuan pemberian pupuk kandang ayam sebanyak 20 ton/ha memberikan pengaruh panjang batang terpanjang. Hal ini menunjukan bahwa pada dosis 20 ton/ha ketersediaan unsur hara yang dibutuhkan oleh tanaman sudah optimal sehingga dapat meningkatkan pertumbuhan tanaman dalam hal ini panjang batang tanaman. Pemberian pupuk kandang ayam 20 ton/ha menjadikan tanah seimbang secara fisik, kimia dan biologi. Menurut Riyo Sumekto (2006) mengatakan bahwa pemberian pupuk kandang ayam dengan dosis 20 ton/ha dapat menunjang ketersediaan unsur hara yang dapat diserap oleh tanaman,sehingga tanaman tumbuh subur. Dengan kandungan N yang terdapat dalam pupuk kandang mempengaruhi

pertumbuhan vegetatif tanaman menjadi lebih baik seperti perkembanagan batang, $\mathrm{P}$ dan $\mathrm{K}$ juga mempunyai peranan penting untuk proses pertumbuhan tanaman diantaranya 
Aksameri: Pengaruh dosis pupuk kandang ayam

merangsang pertumbuhan akar, tidak memanfaatkan bahan organik mempercepat serta memperkuat sebagai bahan makanan dan pertumbuhan tanaman muda menjadi tanaman dewasa (Kartasapoetra dan Sutejo, 1988).

Pada umur 4 mst menunjukan bahwa pemberian pupuk kandang ayam berpengaruh tidak nyata terhadap panjang batang tanaman ubi jalar cilembu. Diduga hal ini dipengaruhi oleh pupuk kandang ayam yang diberikan belum terdekomposisi dengan berpengaruh pada pertumbuhan tanaman dalam hal ini panjang batang, sehingga panjang batang yang tumbuh sudah maksimal.

\section{Jumlah Cabang}

Hasil analisis sidik ragam menunjukan bahwa pemberian pupuk kandang ayam tidak berpengaruh nyata terhadap jumlah cabang tanaman pada berbagai umur pengamatan (Tabel 1.2).

Tabel 1.2 Rataan Jumlah Cabang Tanaman Ubi Jalar Cilembu akibat Perlakuan Dosis Pupuk Kandang Ayam Sebagai Sumber Bahan Organik pada Berbagai umur Pengamatan.

\begin{tabular}{lcccc}
\hline \multirow{2}{*}{ Perlakuan } & \multicolumn{4}{c}{ Rataan jumlah cabang pada umur (mst) } \\
\cline { 2 - 5 } & 2 & 4 & 6 & 8 \\
\hline $\mathrm{K}_{0}$ & 1,00 & 8,00 & 11,00 & 12,00 \\
$\mathrm{~K}_{1}$ & 1,00 & 9,00 & 12,00 & 13,00 \\
$\mathrm{~K}_{2}$ & 2,00 & 9,00 & 12,00 & 14,00 \\
$\mathrm{~K}_{3}$ & 2,00 & 9,00 & 12,00 & 14,00 \\
\hline BN T 5\% & $\mathrm{TN}$ & $\mathrm{TN}$ & $\mathrm{TN}$ & $\mathrm{TN}$
\end{tabular}

Keterangan : Angka yang diikuti oleh huruf yang sama pada kolom yang sama menunjukan tidak berbeda nyata pada taraf $5 \%$ uji BNT.

Pemberian pupuk kandang ayam kandang ayam yang diberikan belum pada berbagai umur pengamatan tidak berpengaruh nyata terhadap jumlah cabang tanaman ubi jalar cilembu. terdekomposisi dengan baik sehingga organism dalam tanah tidak memanfaatkan bahan organik sebagai Diduga hal ini dipengaruhi oleh pupuk bahan makanan dan berpengaruh pada 
pertumbuhan tanaman dalam hal ini jumlah cabang, sehingga jumlah cabang yang tumbuh sudah maksimal. Sedangkan pada umur 6 dan 8 mst tanaman ubi jalar sudah memasuki fase generatif dimana bagian umbi tanaman ubi jalar sudah mulai terbentuk sehingga unsur hara digunakan untuk pembentukan umbi (Wasetiawan, 2009).

Namun dapat dilihat bahwa penggunaan pupuk kandang ayam sebanyak 30 ton/ha menunjukan jumlah cabang yang teringgi. Hal ini menunjukan bahwa

Dosis Pupuk Kandang Ayam Sebagai Sumber Bahan Organik pada Berbagai umur Pengamatan.

\begin{tabular}{lcccc}
\hline Perlakuan & \multicolumn{4}{c}{ Rataan jumlah daun pada umur (mst) } \\
\cline { 2 - 5 } & 2 & 4 & 6 & 8 \\
\hline $\mathrm{K}_{0}$ & 11,00 & 23,00 & 33,00 & $36,00_{\mathrm{a}}$ \\
$\mathrm{K}_{1}$ & 12,00 & 23,00 & 34,00 & $37,00_{\mathrm{a}}$ \\
$\mathrm{K}_{2}$ & 12,00 & 26,00 & 38,00 & $43,00_{\mathrm{b}}$ \\
$\mathrm{K}_{3}$ & 12,00 & 25,00 & 38,00 & $42,00_{\mathrm{b}}$ \\
\hline BN T 5\% & TN & TN & TN & 4,64
\end{tabular}

Keterangan : Angka yang diikuti oleh huruf yang sama pada kolom yang sama menunjukan tidak berbeda nyata pada taraf $5 \%$ uji BNT.

Pemberian pupuk kandang ayam pada umur 2, 4, dan 6 MST memberikan pengaruh yang tidak nyata terhadap pertumbuhan jumlah daun. Diduga dipengaruhi oleh keterbatasan kemampuan tanaman secara genetis pemberian pupuk kandang ayam dapat memberikan pengaruh positif terhadap jumlah cabang, karena unsur hara yang berguna untuk proses metabolisme dalam tubuh tanaman tersedia.

\section{Jumlah Daun (helai)}

Hasil analisis sidik ragam menunjukan bahwa pemberian pupuk kandang ayam berpengaruh nyata terhadap jumlah daun tanaman pada umur 8 MST, serta tidak berpengaruh nyata pada umur 2, 4 dan 6 MST (Tabel $1.3)$.

Tabel 1.3 Rataan Jumlah Daun Tanaman Ubi Jalar Cilembu (helai) akibat Perlakuan 
Aksameri: Pengaruh dosis pupuk kandang ayam

sehingga unsur hara digunakan untuk pembentukan umbi (Wasetiawan, 2009).

Perlakuan pupuk kandang ayam dengan dosis 20 ton/ha dan 30 ton/ha memberikan pengaruh yang tidak nyata terhadap jumlah daun pada umur $8 \mathrm{mst}$, tetapi berbeda nyata dengan kontrol (tanpa pemberian pupuk) dan 10 ton/ha. Hal ini menunjukan bahwa pupuk kandang ayam mengandung unsur hara yang dapat meningkatkan pertumbuhan jumlah daun pada tanaman ubi jalar cilembu. Kartasapoetra dan Sutejo (1988), menambahkan bahwa pupuk kandang ayam mempunyai kemampuan untuk meningkatkan kesuburan tanah, mempertinggi kadar humus, mendorong kehidupan jasad renik dan menambah unsur hara mikro yang dibutuhkan oleh tanamn agar tetap terjadi keseimbangan unsur hara dalam tanah. Menurut Riyo Sumekto (2006) dengan pemberian pupuk kandang ayam maka akan dapat meningkatkan kandungan $\mathrm{N}, \mathrm{P}, \mathrm{K}$ dalam tanah seperti unsur $\mathrm{N}$ yang diperlukan tanaman dalam fase vegetatif, sehingga mempercepat pertumbuhan tanaman, hasil fotosintesis yang terakumulasi akan merangsang tanaman untuk membentuk tunas - tunas daun yang baru.

\section{Luas Daun}

Hasil analisis sidik ragam menunjukan bahwa pemberian pupuk kandang ayam berpengaruh nyata terhadap jumlah cabang tanaman pada berbagai umur pengamatan (Tabel 1.4).

Tabel 1.4 Rataan Luas Daun Tanaman Ubi Jalar Cilembu (cm) akibat Perlakuan Dosis Pupuk Kandang Ayam Sebagai Sumber Bahan Organik pada Berbagai umur Pengamatan.

\begin{tabular}{lcccc}
\hline Perlakuan & \multicolumn{4}{c}{ Rataan indeks luas daun pada umur (mst) } \\
\cline { 2 - 5 } & 2 & 4 & 6 & 8 \\
\hline $\mathrm{K}_{0}$ & $0,35_{\mathrm{a}}$ & $1,20_{\mathrm{a}}$ & $1,35_{\mathrm{a}}$ & $2,31_{\mathrm{a}}$ \\
$\mathrm{K}_{1}$ & $0,40_{\mathrm{ab}}$ & $1,23_{\mathrm{ab}}$ & $1,59_{\mathrm{b}}$ & $2,35_{\mathrm{a}}$ \\
$\mathrm{K}_{2}$ & $0,50_{\mathrm{b}}$ & $1,26_{\mathrm{b}}$ & $1,62_{\mathrm{bc}}$ & $2,50_{\mathrm{a}}$ \\
$\mathrm{K}_{3}$ & $0,51_{\mathrm{b}}$ & $1,27_{\mathrm{b}}$ & $1,65_{\mathrm{c}}$ & $2,56_{\mathrm{a}}$ \\
\hline BN T 5\% & 0,11 & 0,03 & 0,04 & 0,66
\end{tabular}

Keterangan : Angka yang diikuti oleh huruf yang sama pada kolom yang sama menunjukan tidak berbeda nyata pada taraf $5 \%$ uji BNT. 
Pemberian pupuk kandang ayam pada umur 2 dan 4 mst dengan dosis 10 ton/ha, 20 ton/ha dan 30 ton/ha tidak berbeda nyata, tetapi berbeda nyata dengan kontrol (tanpa perlakuan). Pada umur 6 mst, perlakuan dengan dosis 30 ton/ha memberikan indeks luas daun tanaman tertinggi. Hal ini menunjukan bahwa pupuk kandang ayam mengandung unsur hara yang dapat meningkatkan pertumbuhan jumlah daun pada tanaman ubi jalar cilembu. Kartasapoetra dan Sutejo (1988), menambahkan bahwa pupuk kandang ayam mempunyai kemampuan untuk meningkatkan kesuburan tanah, mempertinggi kadar humus, mendorong kehidupan jasad renik dan menambah unsur hara mikro yang dibutuhkan oleh tanamn agar tetap terjadi keseimbangan unsur hara dalam tanah. Menurut Riyo Sumekto (2006) dengan pemberian pupuk kandang ayam maka akan dapat meningkatkan kandungan $\mathrm{N}, \mathrm{P}, \mathrm{K}$ dalam tanah seperti unsur $\mathrm{N}$ yang diperlukan tanaman dalam fase vegetatif, sehingga mempercepat pertumbuhan tanaman, hasil fotosintesis yang terakumulasi akan merangsang tanaman untuk membentuk tunas - tunas daun yang baru.

Pemberian pupuk kandang ayam pada umur 8 MST memberikan pengaruh yang tidak nyata terhadap pertumbuhan luas daun. Diduga dipengaruhi oleh keterbatasan kemampuan tanaman secara genetis dalam pembentukan luas daun, sehingga luas daun yang terbentuk sudah maksimal.

\section{Parameter Produksi}

Hasil analisis sidik ragam menunjukan bahwa pemberian pupuk kandang ayam berpengaruh nyata terhadap berat berangkasan, berat basah umbi pertanaman, panjang umbi, diameter umbi, berat umbi basah per $\mathrm{Ha}$ (Tabel 1.5 ). 
Aksameri: Pengaruh dosis pupuk kandang ayam

Tabel 1.5 Rataan Parameter Produksi Tanaman Ubi Jalar Cilembu akibat Perlakuan Dosis Pupuk Kandang Ayam Sebagai Sumber Bahan Organik pada saat Panen.

\begin{tabular}{lcccccc}
\hline Perlakuan & $\begin{array}{c}\text { Jumlah } \\
\text { umbi basah } \\
\text { pertanaman }\end{array}$ & $\begin{array}{c}\text { Berat } \\
\text { berangkasan } \\
(\mathrm{Kg})\end{array}$ & $\begin{array}{c}\text { Berat basah } \\
\text { umbi } \\
\text { pertanaman } \\
(\mathrm{kg})\end{array}$ & $\begin{array}{c}\text { Panjang } \\
\text { umbi } \\
(\mathrm{cm})\end{array}$ & $\begin{array}{c}\text { Diameter } \\
\text { Umbi } \\
(\mathrm{cm})\end{array}$ & $\begin{array}{c}\text { Berat umbi } \\
\text { basah } \\
\mathrm{kg} / \mathrm{Ha}\end{array}$ \\
\hline $\mathrm{K}_{\mathrm{o}}$ & 4,00 & $2,45_{\mathrm{a}}$ & $1,44_{\mathrm{a}}$ & $20,85_{\mathrm{a}}$ & $5,25_{\mathrm{a}}$ & $496,55_{\mathrm{a}}$ \\
$\mathrm{K}_{1}$ & 4,00 & $2,47_{\mathrm{a}}$ & $1,64_{\mathrm{b}}$ & $21,80_{\mathrm{a}}$ & $5,88_{\mathrm{a}}$ & $575,17_{\mathrm{b}}$ \\
$\mathrm{K}_{2}$ & 4,00 & $3,67_{\mathrm{c}}$ & $2,12_{\mathrm{d}}$ & $24,15_{\mathrm{b}}$ & $7,48_{\mathrm{b}}$ & $731,72_{\mathrm{d}}$ \\
$\mathrm{K}_{3}$ & 5,00 & $2,91_{\mathrm{b}}$ & $1,86_{\mathrm{c}}$ & $23,90_{\mathrm{b}}$ & $6,25_{\mathrm{a}}$ & $640,69_{\mathrm{c}}$ \\
\hline BNT 5 \% & $\mathrm{TN}$ & 0,20 & 0,14 & 1,40 & 1,14 & 49,32 \\
\hline
\end{tabular}

Keterangan : Angka yang diikuti oleh huruf yang sama pada kolom yang sama menunjukan tidak berbeda nyata pada taraf $5 \%$ uji BNT.

Jumlah Umbi Basah Pertanaman

Rataan jumlah umbi basah pertanaman menunjukan bahwa pemberian pupuk kandang ayam tidak berpengaruh nyata terhadap jumlah umbi basah pertanaman pada tanaman ubi jalar cilembu. Hal tersebut diduga dikarenakan terdapat keterbatasan genetis dari tanaman dan juga lingkungan tumbuh tanaman yang kurang mendukung bagi produksi tanaman. Namun dapat dilihat bahwa penggunaan dosis pupuk kandang ayam sebanyak 30 ton/ha menunjukan jumlah umbi basah pertanaman yang paling tinggi yaitu 4,85 . Hal ini menunjukan bahwa pemberian pupuk kandang ayam dapat memberikan pengaruh baik terhadap jumlah umbi basah pertanaman karena unsur hara yang berguna untuk proses metabolisme dalam tubuh tanaman tersedia. Adanya pengaruh baik ini diduga dipengaruhi oleh unsur $\mathrm{K}$ yang terdapat didalam pupuk kandang ayam yang diberikan pada tanaman ubi jalar cilembu. Hasil penelitian Sortha (2006) menunjukan bahwa pupuk kandang ayam mengandung 3,4 \% $\mathrm{K}$. unsur $\mathrm{K}$ secara positif paling membantu dalam proses pembentukan umbi (Sarwono $d k k$, 1990).

\section{Berat Berangkasan (kg)}

Rataan berat berangkasan menunjukan bahwa perlakuan dengan dosis 20 ton/ha pupuk kandang memberikan hasil berat berangkasan terbaik $(3,67 \mathrm{~kg})$ jika dibandingkan dengan kontrol $(2,45 \mathrm{~kg})$. Hal ini menunjukan bahwa pemberian pupuk 
Aksameri: Pengaruh dosis pupuk kandang ayam

kandang ayam sangat berpengaruh terhadap komponen pertumbuhan dan hasil tanaman. Sortha (2006) dalam penelitiannya menjelaskan bahwa pupuk kandang ayam mengandung hara nitrogen 3,6\% N, mengandung hara fosfor $2,9 \% \mathrm{P}$ dan mengandung hara kalium 3,4 \% $\mathrm{K}$ sehinnga biomassa pupuk kandang ayam menjadi salah satu alternatif penyediaan unsur hara yang diperlukan bagi tanaman ubi jalar cilembu.

\section{Berat Basah Umbi Pertanaman (kg)}

Rataan berat basah umbi menunjukan bahwa perlakuan 20 ton/ha pupuk kandang ayam memberikan hasil berat umbi basah pertanaman terbaik $(2,12 \mathrm{~kg})$ jika dibandingkan dengan kontrol dan perlakuan lainnya.hal ini menunjukan bahwa pemberian pupuk kandang ayam dapat meningkatkan hasil tanaman ubi jalar cilembu. Penelitian Tohari Yusuf (2009) menunjukan pemberian pupuk kandang ayam dengan dosis 20 ton/ha dapat meningkatkan umbi ubi jalar varietas lokal hingga mencapai $85 \%$ bila dibandingkan dengan pupuk kandang lainnya. Hasil penelitian Sortha (2006) menunjukan bahwa pupuk kandang ayam mengandung 3,4 \% K. unsur $\mathrm{K}$ secara positif paling membantu dalam proses pembentukan umbi (Sarwono $d k k, 1990)$.

\section{Panjang Umbi (cm)}

Rataan panjang umbi menunjukan bahwa pemberian pupuk kandang ayam dengan dosis 10 ton/ha tidak berbeda nyata dengan kontrol (tanpa pemberian pupuk). Hal ini dikarenakan dosis pupuk yang diberikan sangat sedikit sehinnga tdk berpengaruh nyata terhadap panjang umbi. Namun peningkatan dosis sebanyak 20 ton/ha dan 30 ton/ha menunjukan perbedaan yang nyata dengan kontrol, dengan hasil panjang umbi terbaik pada perlakuan 20 ton/ha $(24,15 \mathrm{~cm})$. Hal ini menunjukan bahwa unsur hara yang terkandung pada pupuk kandang ayam berpengaruh terhadap pembentukan umbi ubi jalar cilembu. Dengan kandungan K yang cukup maka berpengaruh terhadap panjang umbi, sebab unsur $\mathrm{K}$ secara positif paling membantu dalam proses pembentukan umbi. Hal ini akan lebih mempergiat fotosintesis, sebab katalisator $\mathrm{K}$ banyak pengaruhnya, akan semakin banyak karbohidrat yang terbentuk dan semakin banyak terjadi penyimpanan karbohidrat pada umbi dan akhirnya akan semakin memperbesar pembentukan umbi 


\section{Diameter Umbi (cm)}

Rataan diameter umbi menunjukan bahwa pemberian pupuk kandang ayam dengan dosis 10 ton/ha dan 30 ton/ha tidak berbeda nyat dengan kontrol (tanpa pemberian pupuk). Hal ini dikarenakan dosis pupuk yang diberikan 10 ton/ha sangat sedikit sehingga tidak berpengaruh nyata terhadap diameter umbi, dan dosis 30 ton/ha terlalu banyak sehingga tidak berpengaruh nyata juga terhadap diameter umbi. Namun pemberian pupuk kandang ayam dengan dosis 20 ton/ha memberikan pengaruh nyata dengan hasil diameter umbi yaitu $7,48 \mathrm{~cm}$. hal ini menunjukan bahwa pemberian pupuk kandang ayam dapat memberikan pengaruh positifterhadap diameter umbi tanaman ubi jalar cilembu karena unsur hara yang berguna untuk proses metabolisme dalam tubuh tanaman tersedia dengan cukup. Penelitian Tohari Yusuf (2009) menunjukan pemberian pupuk kandang ayam dengan dosis 20 ton/ha dapat meningkatkan umbi ubi jalar varietas lokal hingga mencapai $85 \%$ bila dibandingkan dengan pupuk kandang lainnya. Dengan kandungan $\mathrm{K}$ yang cukup maka berpengaruh terhadap diameter umbi, sebab unsur $\mathrm{K}$ secara positif paling membantu dalam proses pembentukan umbi (Sarwono $d k k$, 1990).

\section{Berat Umbi Basah Per Ha (kg)}

Rataan berat basah umbi per $\mathrm{Ha}$ menunjukan bahwa perlakuan 20 ton/ha pupuk kandang ayam memberikan hasil umbi basah per Ha terbaik $(731,72 \mathrm{~kg})$ jika dibandingkan dengan kontrol (496,55 kg). Hal ini menunjukan bahwa pemberian pupuk kandang ayam dapat meningkatkan hasil tanaman ubi jalar cilembu. Penelitian Tohari Yusuf (2009) menunjukan pemberian pupuk kandang ayam dengan dosis 20 ton/ha dapat meningkatkan umbi ubi jalar varietas lokal hingga mencapai $85 \%$ bila dibandingkan dengan pupuk kandang lainnya. Hasil penelitian Zakaria (2002) menunjukan bahwa pupuk kandang ayam mengandung 3,4 $\% \mathrm{~K}$. unsur $\mathrm{K}$ secara positif paling membantu dalam proses pembentukan umbi (Sarwono $d k k, 1990$ ).

\section{SIMPULAN DAN SARAN}

\section{Simpulan}

1. Pemberian pupuk kandang ayam dapat meningkatkan pertumbuhan dan hasil tanaman ubi jalar cilembu dan berpengaruh nyata terhadap 
panjang batang pada umur 2, 6 dan 8 mst, jumlah daun pada umur 8 mst, dan indeks luas daun pada umur 2, 4 dan 6 mst. Untuk komponen produksi berpengaruh nyata terhadap berat berangkasan, berat basah umbi per tanaman, panjang umbi, diameter umbi, berat umbi basah per/ha

2. Dosis optimum pupuk kandang ayam di peroleh dengan dosis 20 ton/ha yang adapat meningkatkan pertumbuhan panjang batang tanaman ubi jalar cilembu $(80,85 \mathrm{~cm})$ dan hasil tanaman ubi jalar cilembu (731,72 kg/ha).

\section{Saran}

Mengingat pentingnya peranan pupuk kandang ayam sebagai sumber unsur hara yang dapat meningkatkan pertumbuhan dan hasil tanaman ubi jalar cilembu dan ketersediaannya cukup melimpah dan belum dimanfaatkan secara baik oleh petani di Kabupaten Ende maka perlu dilakukan sosialisasi tentang pemanfaatan dan penggunaan dosis pupuk kandang ayam yang tepat.

\section{DAFTAR PUSTAKA}

Anonimus. 2009. Kandungan Hara

Pupuk Kandang.

http://tohariyusuf.word press.com /2009/04/25/kandungan-hara-pupukkandang/. Tanggal 19 Juni 2010. Ashrie. 2009. Sistematika Tanaman Ubi Jalar. http://webcache.googleuserc ontent. Com /search?q=cache: $2 \mathrm{iBRv} 3 \mathrm{iSa}-$ MJ:ashrie.blogspot.com/ 2009/06/ ubi-jalar$\underline{\text { tanamanubijalardalam.html }+}$ $\underline{\text { sistematika+tanaman }+\mathrm{ubi}}$ + jalar

$\& \mathrm{~cd}=10 \& \mathrm{hl}=\mathrm{id} \& \mathrm{ct}=\mathrm{clnk} \& \mathrm{gl}$ =id. Tanggal 01 juni 2010

Dinas Pertanian Kabupaten Ende. 2008. $\begin{array}{lrr}\text { Hasil dan Produksi } \\ \text { Tanaman Ubi } & \text { Jalar. } \\ \text { Kabupaten Ende. } & \end{array}$ Fortuno, E.M., M.B Catany And F.G. Vilamayor, Gr. (1996) Yield Response Obsweet Potato to Fertikeser and Pasticede Aplication. Selected Research Paper, July 1995 Juny 1996, Vol 2. Sweet Potato, ASFRAD. P. 159166. 
Gomez A. Kwanchai dan Gomez A. Arturo. 1995. Prosedur Statistik Untuk Penelitian Pertanian Edisi 2. Universitas Indonesia. Jakarta.

Juanda, D., dan B. Cahyono. 2000. Ubi jalar. Budidaya dan Analisis Usaha Tani. Kanisius. 82 hal.

Kartasapoerta A. G. Dan Sutedjo, M. 1988. Teknologi Budidaya Tanaman Pangan di Daerah Tropik. Bina Aksara. Jakarta.

Lingga, P., Sarwono, IF. Rahardi, P.C. Raharja, J.J. Afriastini, R. Wudianto, dan W.H. Apniaji. 1989. Bertanam ubi-ubian. Penebar Swadaya. 285 hal.

Martin, J.H., and W.H. Leonard. 1967. Principles of field crop production. The Mac Millan Company. London, 1044 pp.

Mimbar, S.M. 1994. Pengaruh Pupuk Kandang Terhadap Terhadap Pertumbuhan dan Hasil Panen Tiga Varietas Kacang Hijau. Agrivita. 18.2.51-56.
Rukmana, R. 1997. Ubi Jalar Budidaya dan Pasca Panen. Kanisius. Yogyakarta.

Setyamidjaja, D. 1996. Pupuk dan pemupukan. Sinaplex Djakarta. 122 hal.

Sitompul, M., Guritno, B. 1995. Analisis Pertumbuhan Tanaman. Yogyakarta : Gajah Mada Universitas Press.

Soemartono. 1998. Ubi jalar. CV. Yasaguna. Jakarta.

Sorhta Simatupang. 2006. Peran Pupuk Organik-Potensi Pupuk Organik Indonesia-Kotoran Ternak-Kebutuhan Pupuk Organik. Http://nuansaonline.net.inde x.php?option $=$ comcontect\&t ask=view\&idItemid $=33$.

Tanggal 04 Mei 2010.

Sulistyowaty dan Santoso. 2001. Fisiologi Tumbuhan. ITB. Bandung.

Sumekto Riyo, R. M.P. 2006. Pupuk Kandang. Citra Aji Parama. Yogyakarta.

Wasetiawan. 2009. Budidaya Ubi Jalar. http://blog.unila.ac.id/waseti awan/files /2009/11/ 
Aksameri: Pengaruh dosis pupuk kandang ayam

budidaya-ubi-jalar.pdf.

Tanggal 10 Mei 2010.

Yusuf Tohari. 2009. Kandungan Hara

Pupuk Kandang.

http://tohariyusuf.

wordpress.

com/2009/04/25/kandungan-

hara-pupuk-kandang/.

Tanggal 06 Desember 2010.

Yuwono, M., Basuki, N., Agustin, L.

2002. Pertumbuhan dan

Hasil Ubi Jalar. Pada

Macam dan Dosis Pupuk

Organik Yang Berbeda

Terhadap Pupuk Anorganik.

Universitas Gajah Mada.

Yogyakarta. 